\title{
PROSES REKRUTMEN DAN SELEKSI KANDIDAT DI INTERNAL PDI PERJUANGAN PADA PILKADA CIMAHI TAHUN 2017
}

\author{
Siti Witianti', Nasrullah Nazsir², Arry Bainus ${ }^{3}$, \\ Mudiyati Rahmatunnisa ${ }^{4}$, dan Mohammad Fazrulzaman Azmi ${ }^{5}$ \\ 1,2,3,4 Universitas Padjadjaran, Bandung, Indonesia \\ ${ }^{5}$ UIN Sunan Gunung Djati Bandung, Bandung, Indonesia \\ E-mail: siti.witianti@unpad.ac.id
}

\begin{abstract}
ABSTRAK. Pada tatanan negara demokrasi, lazimnya partai politik melakukan upaya perekrutan calon kandidat yang akan menduduki jabatan-jabatan strategis. Oleh karena itu, partai politik harus menyediakan kader-kadernya yang siap mengikuti seleksi di intenal partai. Pada kasus Pilkada Kota Cimahi tahun 2017, Paslon yang terpilih bukan dari kader PDI Perjuangan, karena penjaringan dilakukan secara terbuka bagi kader dan non kader. Dengan demikian tujuan penelitian dilakukan untuk mengetahui dinamika dan metpde seleksi yang dilakukan PDI P Perjuangan dalam pencalonan walikota dan wakil walikota di Kota Cimahi pada tahun 2017. Penelitian ini menggunakan pendekatan kualitatif dengan mengamati dan mendengarkan narasumber untuk mendapatkan pemahaman holistik. Pengumpulan data dilakukan dari unsur internal dan eksternal PDI Perjuangan dan beberapa bakal calon dari kader dan bukan PDI Perjuangan, sedangkanengumpulan data primer dilakukan melalui wawancara mandalam sedangkan penentuan informan dilakukan berdasarkan purposive technique. Adapun hasil dari penelitian ini adalah Tim Seleksi tingkat lokal tidak hanya melaksanakan fungsi prosedural dalam proses seleksi, akan tetapi ada peran lebih dalam melakukan screening bakal calon, khususnya mengenai komitmen yang akan diberikan kepada partai. Dominasi dan kuatnya kewenangan DPP dalam memutuskan hasil seleksi masih sangat mencolok, termasuk tim seleksi pusat pun akan sangat bergantung dengan keputusan DPP, meskipun tahapan prosedural sudah secara rinci dilaksanakan. Proses penentuan calon dapat dikatakan dinamis di tingkat lokal, namun setelah mencapai tahap akhir, dinamika tersebut terhenti oleh kebijakan DPP yang berwenang untuk memutuskan dan merekomendasikan calon untuk berkontestasi dalam Pemilu. Hal yang menarik lainnya dalam proses pencalonan di internal PDI-P Kota Cimahi adalah tidak adanya mahar politik, namun bakal calon diminta komitmennya untuk membiayai pemenangan Pilkada. Selanjutnya, penelitian ini menunjukan adanya keterbatasan desentralisasi kewenangan dalam proses rekrutmen. Kesimpulan dari penelitian ini terdapat pengaruh kekuatan oligarki dalam proses rekrutmen dan seleksi kandidat, serta kekuatan finansial yang dapat mengimbangi pengaruh tersebut.
\end{abstract}

Kata kunci: Rekrutmen; PDI Perjuangan; Pilkada; Cimahi

\section{CANDIDATE RECRUITMENT AND SELECTION PROCESS IN PDI PERJUANGAN IN CIMAHI ELECTION 2017}

\begin{abstract}
In a democratic country, political parties usually make efforts to recruit candidates who will occupy strategic positions. Therefore, political parties must provide their cadres who are ready to take part in the internal party selection. In the case of the Cimahi City local election (Pilkada) in 2017, the selected candidate were not from PDI Perjuangan (PDIP) cadres, because the selection was done openly for cadres and non-cadres. Thus, the purpose of the study was to find out the dynamics and selection methods carried out by PDIP in the nomination of mayor and deputy mayor in Cimahi City in 2017. This study used a qualitative approach by observing and listening to sources to get a holistic understanding. Data collection was carried out from internal and external elements of the PDIP and several prospective candidates from cadres and not PDIP, while primary data was collected through in-depth interviews while the determination of informants was carried out based on a purposive technique. The result of this research is that the local-level Selection Team does not only carry out procedural functions in the selection process, but has a more important role in screening prospective candidates, especially regarding the commitments that will be given to parties. The dominance and strength of the DPP's authority in deciding the results of the selection is still very conspicuous, including the central selection team which will depend heavily on the DPP's decision, even though the procedural stages have been carried out in detail. The process of determining candidates can be said to be dynamic at the local level, but after reaching the final stage, the dynamics are stopped by the DPP's policy which is authorized to decide and recommend candidates to contest in the General Election. Another interesting thing in the internal nomination process in the PDIP at Cimahi City is that there is no political dowry, but prospective candidates are asked for their commitment to finance the election victory. Furthermore, this study shows the limitations of decentralization of authority in the recruitment process. The conclusion of this study is that there is an influence of oligarchic power in the recruitment and selection process of candidates, as well as financial strength that can offset this influence.
\end{abstract}

Keywords: Recruitment; PDI Perjuangan; Regional Elections; Cimahi 


\section{PENDAHULUAN}

Pada tatanan negara demokrasi, lazimnya partai politik melakukan upaya perekrutan calon kandidat yang akan menduduki jabatan-jabatan strategis, yang berpengaruh besar terhadap jalannya suatu pemerintahan (Dalton, et al, 2011). Umumnya, hal yang disoroti dalam proses tersebut adalah dasar atau alasan partai politik dalam memilih individu, yang kemudian akan dipromosikan sebagai calon pejabat publik. Terdapat berbagai kriteria yang diterapkan dalam proses rekrutmen, seperti halnya dalam Peratuan Partai Demokrasi Indonesia Perjuangan (PDIP) No. 24 tahun 2017 tentang Proses Penjaringan dan Penyaringan dalam Pilkada. Peraturan tersebut membahas tentang persyaratan apa saja yang harus dilengkapi oleh bakal calon, yang salah satunya adalah berkomitmen secara tertulis untuk memperjuangkan kepentingan partai, serta turut serta berkontribusi dalam membiayai pemenangan.

Proses rekrutmen calon dalam Pilkada di Indonesia senantiasa menarik untuk diteliti, seperti halnya pada Pilkada Cimahi tahun 2017, terdapat tiga pasangan calon, yaitu: 1) Atty Suharti dan Achmad Zulkarnain; 2) Asep Hadad Didjaya dan Irma Indriyani; 3) Ajay M. Priatna dan Ngatiyana. Ketiga pasangan calon tersebut diusung oleh partai politik, nomor urut satu diusung oleh Golkar, PKS dan Nasdem, nomor urut dua diusung oleh Gerindra dan Demokrat, nomor urut tiga diusung oleh Partai Demokrasi Indonesia Perjuangan (PDIP), Partai Persatuan Pembangunan (PPP), Partai Kebangkitan Bangsa (PKB), dan Partai Amanat Nasional (PAN). Pada proses rekrutmen tersebut pasangan nomor urut tiga paling menarik untuk diteliti, selain karena diusung oleh partai terbanyak, kemudian mendapatkan dukungan dari dua partai lain yaitu Hanura dan Perindo, hal tersebut menujukan adanya berbagai dinamika dalam proses rekrutmen dan seleksi kandidat, khususnya di internal PDI Perjuangan.

Pada proses rekrutmen dan seleksi kandidat tersebut diawali dengan tahapan penjaringan, kemudian penyaringan, pengambilan keputusan dan pengesahan surat rekomendasi dan pendaftaran ke KPU. Proses penjaringan diawali dengan pengumuman pihak DPC PDI Perjuangan (PDIP) Cimahi didampingi DPD PDIP Jawa Barat ke berbagai media massa, bahwa DPC PDIP membuka penjaringan kandidat. Sebagaimana pernyataan Ketua DPC PDIP Cimahi saat itu, Denta Irawan pendaftaran bakal calon dimulai pada tanggal 13 Februari 2016 dan diakhiri pada tanggal 27 Februari 2016 (Febriani, 2016). Kemudian, pada tanggal 28 Februari 2016, DPC PDIP Kota Cimahi merilis sepuluh nama bakal calon yang akan berkontestasi memperebutkan rekomendasi PDI Perjuangan untuk menjadi calon dalam Pilkada Cimahi 2017. Selanjutnya, pada tanggal 11 Maret 2016, hasil penjaringan DPC PDIP Cimahi bertambah lagi satu, sehingga menjadi sebelas orang. Kemudian, pada tanggal 8 November 2016, muncul nama seorang TNI aktif yang masuk dalam penjaringan tahap dua, yaitu Letkol Yana (Ngatiyana) (Irawan, 2016).

Penambahan nama bakal calon di luar dari agenda yang dijadwalkan pun menjadi menarik untuk dikaji lebih dalam, hal ini disebabkan dinamisnya proses rekrutmen dan lobi politik, baik itu di tingkat lokal maupun nasional. Penambahan Encep dan Agung mengindikasikan adanya peran elit politik lokal yang turut serta memberikan akses kemudahan agar mereka dapat mengikuti bursa penjaringan, bahkan nama Agung Yudaswara dikonfirmasi oleh Andi, Sekretaris DPC PDIP Cimahi masuk ke tahapan penyaringan di DPP. Selanjutnya, munculnya nama Letkol Ngatiyana mengindikasikan adanya peran elit pusat yang 'menitipkan' namanya di DPP PDI Perjuangan untuk kemudian diproses di tingkat DPC dan DPD. Nama Ngatiyana tersebut sempat memunculkan polemik, dikarenakan statusnya sebagai TNI aktif. ${ }^{1}$

Kemudian, ada yang menarik dalam tahapan penjaringan tersebut, bahwa seluruh bakal calon tidak diminta mahar politik. Bahkan Sekjen PDI Perjuangan, Hasto Kristianto (dalam Hanifah, 2016) menjelaskan akan memecat kadernya yang meminta mahar politik kepada bakal calon maupun calon. Hal ini pun dikonfirmasi oleh Ikin Sodikin, salah satu peserta penjaringan, ia mengatakan bahwa tidak ada mahar dalam pencalonan di PDIP, akan tetapi calon diminta komitmennya untuk mendanai biaya pemenangan. Hal ini pun dikuatkan dalam Peraturan PDIP No. 24 Tahun 2017, bahwa bakal calon diminta untuk menyepakati komitmen tertulis dalam pendanaan operasional pemenangan Pilkada, serta bersedia dan berkomitmen sebagai petugas partai yang harus sejalan dengan arah perjuangan partai dan mengutamakan kepentingan partai, termasuk dalam menempatkan kader-kadernya di jabatan strategis pemerintahan.

Setelah uji komitmen dan survei internal maupun yang melibatkan pihak eksternal untuk pemetaan politik, tahapan selanjutnya adalah penyaringan nama yang masuk ke DPP. Ikin Sodikin, memberikan kesaksian bahwa terdapat tiga nama yang disetorkan ke DPP, yaitu Ikin, Iskandar, dan Agung. Tiga nama tersebut dipandang lolos uji komitmen, dan berpeluang berdasarkan hasil survei internal maupun eksternal. Akan tetapi, hasil dari penyaringan di DPP adalah nama Letkol Ngatiyana, ketiga nama tersebut tidak lolos atau ${ }^{1}$ Hasil Wawancara dengan Ikin Sodikin, Peserta Penjaringan Non Kader DPC PDIP Cimahi, di Kampus Pascasarjana Unpas, Tanggal 21 Oktober 2020, Pukul 14.00-selesai. 
tidak direkomendasikan sebagai calon oleh DPP PDI Perjuangan. ${ }^{2}$

Munculnya nama Ngatiyana sebagai calon yang direkomendasikan oleh partai menimbulkan pertanyaan besar bagi peserta penjaringan lain, maupun publik pada umumnya. ${ }^{3}$ Karena pihak DPC PDIP Cimahi, Denta Irawan mengakui bahwa saat itu Letkol Ngatiyana memiliki elektabilitas dan popularitas yang rendah, bahkan tidak dikenal oleh masyarakat Cimahi. ${ }^{4}$

Selanjutnya, pekerjaan DPC adalah mencari pasangan dari Ngatiyana untuk kemudian dicalonkan sebagai pasangan calon pada Pilkada Cimahi 2017. Nama Ajay M. Priatna yang sebelumnya mengikuti tahapan penjaringan, namun gugur karena terpilihnya Ngatiyana, muncul kembali dengan membawa dukungan dari tiga partai. Denta Irawan, mantan Ketua DPC PDIP Cimahi mengkonfirmasi bahwa Ajay telah mengantongi dukungan dari tiga partai, yaitu PPP, PKB, dan PAN. ${ }^{5}$ Kemudian, Tim koalisi pengusung Ajay sepakat untuk bergabung dengan PDIP, serta kedua tim menyepakati untuk mengusung Ajay-Ngatiyana sebagai pasangan calon yang diusung oleh PDIP, PPP, PKB, dan PAN, untuk berkontestasi pada Pilkada Cimahi $2017 .^{6}$

Dinamika proses rekrutmen yang meng-hasilkan pasangan Ajay-Ngatiyana menarik untuk diteliti lebih lanjut, baik itu pendalaman analisis majunya Ngatiyana sebagai wakil PDI P, serta majunya Ajay sebagai wakil dari PPP, PKB dan PAN. Selain itu, dinamika dalam pengusungan pasangan calon tersebut menarik untuk dibahas lebih dalam, khususnya di internal PDIP yang sempat menggagalkan nama Ajay dalam proses penjaringan, namun hasilnya justru Ajay menjadi nomor satu (calon walikota), sedangkan Ngatiyana menjadi nomor dua (calon wakil walikota) pada Pilkada Cimahi 2017.

Landasan teroritis dalam penelitian ini diawali dengan menyajikan konsep Partai politik yang menyebutkan bahwa partai politik merupakan suatu lembaga politik atau organisasi yang berkaitan dengan pemilihan umum Karena partai politik (Parpol) merupakan lembaga resmi yang dapat berpartisipasi dalam pemilihan umum (Pemilu), khususnya sebagai peserta yang berkontestasi, maka setiap partai berusaha untuk menjadi pemenang Pemilu (Axford, 1997; Djuyandi, 2018).

Selanjutnya, dalam mengkaji fenomena ini teori Rahat dan Hazan (dalam Katz dan Crotty, 2014: 180) mengenai prosedur dalam mengklasifikasikan metode seleksi calon digunakan peneliti untuk ${ }^{2}$ Ibid.

${ }^{3}$ Ibid.

${ }^{4}$ Hasil Wawancara dengan Denta Irawan, Mantan Ketua DPC Cimahi, Melalui Sambungan Telepon, pada Tanggal 7 November 2020, Pukul 16.20-Selesai.

Ibid.

${ }^{6}$ Ibid. menguraikan sekaligus mendeskripsikan berbagai fenomena menarik yang terjadi saat proses rekrutmen internal PDIP pada Pilkada Cimahi 2017. Rahat dan Hazan (dalam Katz dan Crotty, 2014: 180) berpendapat bahwa diperlukan suatu prosedur atau aturan untuk mengklasifikasikan metode seleksi calon, yang dapat dilakukan dengan empat kriteria, yaitu: 1) Selektorat, yaitu membentuk badan atau tim seleksi yang bertugas untuk menyeleksi calon. 2) Pencalonan, membahas tentang, tahapan proses pencalonan, sehingga dapat menghasilkan calon yang direkomendasikan atau didukung oleh partai. 3) Desentralisasi, kebijakan dan kewenangan penetapan seleksi calon diberikan pada pengurus partai di tingkat daerah; 4) Voting Versus Penunjukkan. Pengangkatan calon biasanya dilakukan pada selektorat yang lebih kecil dan lebih ekslusif, sedangkan voting biasanya dilakukan pada selektorat yang lebih besar. Empat prosedur tersebut dapat digunakan untuk memahami dan menggambarkan dinamika proses rekrutmen dan seleksi yang terjadi pada suatu partai politik dalam menghadapi Pilkada.

Peneliti sadari bahwa penelitian ini tidak lepas dari keterkaitan dengan penelitian terdahulu lainnya yang sejenis dengan penelitian ini. Berikut merupakan penelitian yang dianggap relevan dan mendekati tema penelitian ini:

Pertama, penelitian yang membahas tentang rekrutmen politik. Terdapat riset yang membahas tentang hal-hal yang menyebabkan tidak relevannya sistem pemilu dengan pejabat publik yang dihasilkan karena fungsi rekrutmen partai politik yang tidak optimal, sehingga berpengaruh besar terhadap kualitas pejabat politik (Sianturi, 2015).

Kedua, penelitian yang membahas tentang rekrutmen dan seleksi kandidat dalam pilkada, riset yang membahas Keputusan Mahkamah Konstitusi (MK) Tahun 2015 dalam membatalkan larangan terhadap politik dinasti, sehingga keluarga petahana dapat berkontestasi dalam pilkada. Pada riset ini dijelaskan bahwa latar belakang dinasti politik adalah masalah dalam proses rekrutmen politik, hal ini menggambarkan pencalonan pilkada yang bersifat sentralistis, informal, dan pragmatis karena mensyaratkan kemampuan finansial dan elektabilitas calon (Fitriyah, 2020). Selanjutnya, riset yang membahas rekrutmen calon kepala daerah oleh Gerindra. Keputusan rekrutmen tersebut tersentralisasi pada Ketua Dewan Pembina dan ketuan Badan Seleksi Calon Kepala Daerah, sehingga partai tidak merepresentasikan lembaga demokrasi. Namun, jika kewenangan tersebut diberikan pada tingkatan pengurus DPD atau setingkat provinsi maupun DPC atau setingkat Kabupaten/Kota, maka pengurus partai pusat atau DPP akan kehilangan sumber finansial dan kekuasaan (Kartini, 2015). 
Ketiga, riset yang membahas tentang rekrutmen di PDI Perjuangan, terdapat riset yang membahas tentang pola rekrutmen calon anggota DPRD oleh PDI P menjelang Pemilu 2014 di Kota Semarang. Pola rekrutmen tersebut atas dasar perintah DPP yang harus melalui prosedur pendaftaran, penjaringan, tes administrasi, penyaringan dan penugasan. Pada riset ini ditemukan bahwa partai sulit menemukan caloncalon yang sesuai dengan kriterianya (Ariwibowo, et.al, 2013).

Berdasarkan hasil kajian terhadap beberapa penelitian terdahulu tersebut, penelitian ini melihat bahwa meskipun terdapat kesamaan dalam meneliti rekrutmen politik, khususnya dalam pilkada, namun penelitian-penelitian tersebut tidak meneliti tentang kekuatan pengaruh oligarki dan pengaruh kekuatan finansial dalam penentuan posisi calon walikota dan calon wakil walikota. Riset ini menekankan pada kekuatan oligarki politik dan kekuatan finansial dalam menghadapi high cost politics dalam proses rekrutmen politik tersebut. Melalui penelitian ini secara tidak langsung kita dapat mengklasifikasikan pola yang terjadi dalam pencalonan walikota kota cimahi tahun 2017. Rekrutmen politik bisa diklasifikasikan ke dalam empat modelsebagaimana dikemukakan Geddes (dalam Labolo, 2015) adalah sebagai berikut:

1. Partisanship, yaitu rekrutmen politik berdasarkan loyalitas calon pada partai, sehingga kurang memperlihatkan adanya kompetisi dalam seleksi;

2. Meritockratic, rekrutmen politik berdasarkan kompetensi atau keahlian khusus yang diperlukan oleh partai.

3. Compartmentalization, rekrutmen politik berdasarkan meritokratis informal;

4. Survival, rekrutmen politik berdasarkan balas jasa, sehingga cenderung menimbulkan partronase politik.

Model klasifikasi rekrutmen politik tersebut memberikan sebuah gambaran tipe rekrutmen politik yang dilakukan oleh setiap partai politik, dengan demikian partai politik memiliki kewenangan penuh dalam menyeleksi calon kandidat untuk menduduki posisi jabatan tertentu. berkaitan dengan kajian penelitian ini, maka model survival cenderung oligarkis, karena mengedepankan prinsip balas jasa dan patronase. Dengan adanya politik balas jasa dan patronase, maka tidak ada keseimbangan antara patron dan klien, sehingga nuansa oligarkis lebih terlihat. Selanjutnya, pola survival pun dapat dikatakan sebagai bagian dari model descriptive style.

\section{METODE}

Riset ini menggunakan desain pendekatan kualitatif, mengacu pada pendapat Cresswell (2004) yang menjadi ciri dari penelitian kualitatif salah satunya adalah peneliti berperan sebagai instrumen utama yang memberikan perspektif, penyajian data atau narasi penjelasan penelitian bersifat deskriptif, lebih mengedepankan makna dari proses penelitian.

Proses pengumpulan data dalam penelitian ini dilakukan dari primer dan sekunder. Data primer dilakukan melalui wawancara mandalam, data sekunder dilakukan dengan mengumpulkan bahan-bahan berupa buku, e-book, jurnal, e-journal, pemberitaan media, peraturan perundangan, dan dokumen lainnya yang relevan dalam penelitian ini.

Langkah yang dilakukan dalam mengumpulkan data penelitian terdiri dari beberapa teknik, antara lain dengan wawancara mendalam dan dokumentasi. Informan ditentukan dengan menggunakan teknik purposif, berikut merupakan informan yang telah ditentukan dalam penelitian ini:

1) Mantan Ketua DPC PDI Perjuangan Periode 2012 s.d. 2017;

2) Ketua DPRD Kota Cimahi /Anggota PDIP Kota Cimahi;

3) Ketua Bidang Hukum dan Politik DPC PDI Perjuangan selaku Penanggungjawab tahap Rekrutmen di DPC PDI Perjuangan Kota Cimahi;

4) Bakal Calon dari kader PDI Perjuangan;

5) Bakal Calon bukan kader PDI Perjuangan;

6) Ketua KPU Kota Cimahi.

Adapun prosedur yang digunakan peneliti dalam menguji validitas data penelitian ini adalah dengan melakukan triangulasi atau pengecekan data hasil penelitian dengan sumber data lainnya, jika ditemukan data yang kurang jelas maka dilakukan penelitian ulang.

\section{HASIL DAN PEMBAHASAN}

\section{Peran Tim Seleksi}

Pembahasan seputar dinamika rekrutmen pada Pilkada Cimahi tahun 2017 di internal PDIP tidak luput dari pengelolaan kewenangan Tim Seleksi tingkat DPC yang hanya ditugaskan untuk melakukan penjaringan dan mengelola berkas administrasi bakal calon untuk diantarkan ke DPD dan DPP. Denta Irawan, Mantan Ketua DPC Cimahi saat Pilkada 2017 menyatakan bahwa Tim Seleksi di tingkat DPC itu memang diperlukan, namun tidak memiliki kewenangan, khususnya dalam menganulir atau mendiskualifikasi bakal calon dalam proses penjaringan. ${ }^{7}$ Selain itu, untuk mengkonfirmasi pernyataan Denta melalui metode triangulasi, Yus Rusnaya, Mantan Anggota DPRD Cimahi, Fraksi PDI Perjuangan, menjelaskan bahwa terdapat Tim

Hasil Wawancara dengan Denta Irawan, Mantan Ketua DPC PDIP Cimahi, Loc.Cit. 
Khusus/Tim Seleksi di DPC untuk melakukan penjaringan dan mengajukan nama-nama bakal calon kepada DPD untuk kemudian direkomendasikan kepada DPP. ${ }^{8}$ Dengan demikian, dapat diketahui bahwa wewenang Tim Khusus/Tim Seleksi di tingkat DPC dan DPD hanya sebatas administratif, kemudian DPD dapat merekomendasikan hasil penjaringan kepada DPP, sehingga keputusan final ada di DPP.

Tim Seleksi dari DPC Cimahi terdiri dari internal pengurus DPC, sebagaimana informasi dari Andi, mantan Sekretaris DPC PDI P Cimahi bahwa Tim Rekrutmen saat itu terdiri dari beberapa orang, antara lain adalah Hendrik, Dadan, Maspur, lima orang lainnya dari tim sekretariat, dan seluruh jajaran struktur. ${ }^{9}$ Kemudian, Andi, mantan Sekretaris DPC PDIP Cimahi menjelaskan bahwa tugas dari Tim Seleksi di tingkat DPC adalah mengumumkan penjaringan, menerima bakal calon, menerima dokumen-dokumen bakal calon, mengirimkan hasil penjaringan ke DPP, serta mendaftarkan hasil seleksi ke KPU. ${ }^{10}$ Dengan demikian, dapat dipahami bahwa secara prosedural peran Tim Seleksi di tingkat DPC tidak lebih dari pelaksanaan agenda penjaringan dan pendokumentasian penjaringan kandidat.

Selanjutnya, peran lain yang tidak dijelaskan dalam aspek prosedural adalah lobilobi politik antara Tim Seleksi dan bakal calon. Jika dicermati bahwa syarat prosedural dalam proses seleksi mengharuskan bakal calon untuk berkomitmen terhadap kepentingan partai pasca diraihnya kemenangan Pilkada, khususnya dalam memberdayakan kader partai di posisi strategis pemerintahan. Selain itu, dalam konteks relasi pasca diraihnya kemenangan, bakal calon diminta untuk menyepakati bahwa ia dinyatakan sebagai petugas partai yang menduduki jabatan politik dalam pemerintahan. Begitu pun dengan komitmenkomitmen politik lainnya, khususnya dalam proses pemenangan, terkait kontribusi pendanaan biaya survei, biaya APK, biaya kampanye, biaya mobilisasi Regu penggerak pemilih (Guraklih), biaya saksi, dll. Fenomena ini menggambarkan bahwa, DPC tidak hanya melaksanakan fungsi prosedural dalam proses seleksi, akan tetapi ada peran lebih dalam melakukan screening bakal calon, khususnya mengenai komitmen yang akan diberikan kepada partai, baik itu ketika proses maupun pasca pemenangan Pilkada.

Kemudian, kuatnya pengaruh DPP, khususnya ketua umum partai dalam proses seleksi, khususnya dalam menetapkan hasil rekrutmen mengindikasikan

\footnotetext{
${ }^{8}$ Hasil Wawancara dengan Yus Rusnaya, Anggota DPRD Cimahi, di Jl. Encep Kartawiria 148, pada Tanggal 14 November 2020, pukul 13.30-selesai.

${ }^{9}$ Hasil Wawancara dengan Andi, Mantan Sekretaris DPC PDIP Cimahi, di Cibereum Cimahi, Pukul 09.00-selesai. ${ }^{10} \mathrm{Ibid}$.
}

kuatnya pengaruh segelintir elit yang cenderung melaksanakan praktik oligarkis dalam tubuh partai politik. Hal ini tentu dapat mencederai demokratisasi partai yang sudah jelas memiliki aturan prosedural dalam proses rekrutmen, namun secara substantif prosedur demokratis tersebut terhalang dengan kuatnya pengaruh dan kewenangan segelintir pihak. Otoritas terkuat dalam proses seleksi ini adalah DPP, sehingga pengaruh oligarki politik di tubuh partai politik sangatlah kuat, DPC hanya bisa menjalankan keputusan DPP. Akan tetapi, hal ini tidak menutup ruang lobi politik, proses negosiasi antara pengurus DPC dan bakal calon dapat membuka ruang lain. Selain itu, DPP tetap membuka masukan pihak DPC yang akan berkontestasi di lapangan.

Catatan mendasar dari pola kewenangan yang sentralistik adalah kembali pada aturan rekrutmen politik yang berasaskan pada kemampuan kandidat dan kesiapan kandidat untuk memimpin dan menempati jabatan publik. Apabila yang menjadi kriteria utama penentu kebijakan partai adalah basis kedekatan, maka dampaknya pola yang terbentuk tidak terlepas dari patronase politik. Dengan demikian, menjadi jelas bahwa rekrutmen bukan hanya persoalan mencari anggota baru atau kandidat untuk berkontestasi dan menempati jabatan-jabatan tertentu, akan tetapi dalam kerangka ini dipahami bahwa rekrutmen politik menggambarkan citra partai itu sendiri di hadapan publik. Sebagaimana pendapat Marsh (dalam Katz dan Crotty, 2014: 192) bahwa proses seleksi calon tidak hanya mempengaruhi dinamika partai politik, akan tetapi dapat mencerminkan partai politik itu sendiri di mata masyarakat.

Selanjutnya yang perlu dicermati adalah rangkaian tugas prosedural dan non prosedural yang diterima oleh Tim Seleksi di tingkat DPC. Pada tingkatan DPC, tugas dasar tim seleksi sebagai pengelola administrasi dan pendokumentasian proses penjaringan. Namun karena pada prosesnya ruang lobi politik dalam memastikan komitmenkomitmen politik itu juga ada di tingkat DPC, sehingga secara tidak langsung Tim Seleksi di tingkat DPC pun berperan untuk menyaring kandidat. Meskipun yang dibahasakan oleh para pengurus DPC bahwa tim seleksi di tingkat kabupaten/kota hanya berperan sebagai penyeleksi administrasi dan pendokumentasian, namun lebih jauh dari itu terdapat peran strategis yang dimilikinya dalam ruang lobi politik di tingkat lokal. Salah satu contohnya digambarkan Denta Irawan yang menyebutkan terjadi lobi pada saat tiba-tiba DPP mengambil keputusan dengan mengeluarkan SK terkait pasangan calon yang direkomendasikan oleh DPP atas nama Ajay dan Denta sebagai pasangan calon walikota dan wakil walikota, sedangkan Denta tidak sama sekali 
mengikuti proses penjaringan dan seleksi kandidat pada saat itu, lobi tersebut berhasil dilakukan dengan akirnya nama Denta diganti dengan Ngatiyana.

Berdasarkan uraian di atas peneliti sependapat dengan Cross dan Bottomore (dalam Pamungkas, 2012) yang menjelaskan bahwa ketika memahami rekrutmen politik, maka dapat membantu peneliti dalam memetakan letak kekuasaan suatu partai, baik itu sentralistik atau tersebar. Fenomena rekrutmen di internal PDIP pada Pilkada Kota Cimahi tahun 2017 menggambarkan letak kekuasaan yang sentralistik. Hal ini ditandai dengan kewenangan DPP dalam memutuskan hasil rekomendasi kandidat yang akan dicalonkan dan berkontestasi dalam Pilkada. Akan tetapi, pada proses penetapan hasil akhir terdapat relasi antara elit partai pusat dan lokal, sehingga hasil keputusan pun tetap memperhatikan dinamika yang terjadi di daerah.

\section{Seleksi Kandidat di Internal PDIP Pada Pilkada Cimahi 2017}

Prosesseleksidiawalidengantahapanpenjaringan, DPC bertugas mengumumkan kepada masyarakat termasuk ke berbagai media. Sebagaimana pernyataan dari Yus Rusnaya, mantan Anggota DPRD Kota Cimahi, bahwa DPC Partai Cimahi mengumumkan tahapan penjaringan ini kepada publik, kemudian para kompetitor itu berdatangan, ada pun motifnya adalah ingin direkomendasikan oleh partai besar. DPC PDI P saat itu tampil percaya diri, dikarenakan memiliki kursi terbanyak di DPRD Cimahi, serta memimpin dalam kepemimpinan nasional, baik itu di eksekutif maupun legislatif. Asumsi tersebut memang umumnya dapat diterima, namun faktanya dinamika rekrutmen di internal partai tidak mudah dipetakan, prosesnya sangat cair, karena terdapat berbagai variabel yang mempengaruhi kebijakan politik partai dalam merekomendasikan kandidat, khususnya kepentingan elit partai yang sulit untuk dipetakan pengurus di tingkat daerah sebagaimana yang dikemukakan Denta Irawan mantan ketua KPUD Kota Cimahi Ketika menjelaskan dinamika terpilihnya Ajay dan Ngatiyana dalam pencalonan tersebut seperti pertimbangan finansial, popularitas, instruksi DPP PDIP, dan lavinnya. Dengan demikian, pengurus di daerah dan tokoh-tokoh yang mendaftar penjaringan perlu memperhatikan resiko tersebut, dan memahami bahwa proses politik dalam pencalonan sangatlah cair. Catatan lainnya dalam konteks ini adalah untuk mencalonkan diri dan direkomendasikan partai, tidak cukup dengan hanya modal finansial yang besar, namun calon kandidat beserta timnya perlu membangun kekuatan pengaruh lain, baik itu dari lobi politik di tingkat daerah, maupun relasi kedekatan dengan elit partai yang memiliki pengaruh terhadap rekomendasi partai.
Peneliti mencermati bahwa konteks proses rekrutmen yang terbuka dapat dilihat dari pola DPD dan DPC dalam mengumumkan penjaringan terbuka, kemudian mensosialisasikan kandidat pada konstituen partai, seakan memberikan gambaran bahwa proses tersebut transparan dan dapat diakses oleh publik. Akan tetapi, faktanya, proses rekrutmen yang tertutuplah yang menghasilkan keputusan akhir di internal PDI Perjuangan, yang selanjutnya akan dijelaskan pada tahapan analisis hasil penyaringan. Yus Rusnaya, mantan Anggota DPRD Kota Cimahi kembali menjelaskan bahwa dalam tahapan penjaringan ini bertujuan untuk menjaring bakal calon yang siap berkontestasi dengan petahana dan siap berjuang untuk memenangkan Pilkada. Denta Irawan, mantan Ketua DPC PDIP Cimahi menjelaskan bahwa tahapan penjaringan ini bisa dilakukan oleh setiap tingkatan dalam partai, namun kewenangan utamanya ada di DPP. Denta menambahkan bahwa meskipun tahapan penjaringan bisa dilakukan di setiap tingkatan, namun DPD maupun DPP tetap menyarankan untuk diproses melalui DPC terlebih dahulu, kemudian secara teknis DPC menyiapkan formulir sesuai dengan ketentuan DPP, serta mengumumkan tanggal pembukaan dan batas akhir waktu pengumpulan formulir tersebut, yaitu dimulai pada tanggal 13 Februari 2016 sampi dengan tanggal 27 Februari 2016. Pernyataan Denta dan Yus Rusnaya mengambarkan bahwa PDI Perjuangan ingin mencitrakan proses rekrutmen yang terbuka, sehingga publik dapat memantau proses rekrutmen tersebut. Selain itu, peliputan terhadap kegiatan partai yang kemudian diberitakan kepada publik menjadi keuntungan tersendiri bagi partai, sebab proses tersebut menjadi sarana sosialisasi politik kepada masyarakat Kota Cimahi.

Selanjutnya, pada tanggal 28 Februari 2016 muncul sepuluh nama hasil penjaringan DPC Cimahi, yaitu M. Dennis Titanio yang berlatarbelakang pengusaha, Ence Tarman Suwandi yang merupakan kader PDI P dan pengusaha, Armed sebagai Politisi PBB, Ikin Sodikin yang merupakan mantan Ketua KPU Kota Cimahi, Bambang Arie yang latar belakangnya mantan Sekda Kota Cimahi, M. Iskandar Subrata mantan Sekda Kota Cimahi, Dadan Kurniansyah kader PDIP dan akademisi, Ajay M. Priatna yang merupakan seorang Pengusaha, Yusuf Zainal Abidin sebagai Tokoh Ulama Cimahi, Maktal S. Nugraha sebagai Direktur BUMD PD. Jati Mandiri Kota Cimahi. Hasil dari penjaringan tersebut dapat dikatakan sukses, sebab yang mendaftarkan diri sebagai bakal calon umumnya merupakan tokoh yang berpengaruh di Cimahi, seperti halnya mantan sekretaris darah, tokoh ulama, dan mantan pimpinan KPU. 
Kemudian, pada tanggal 11 Maret 2016, DPC PDIP mengumumkan bahwa hasil penjaringan tersebut menghasilkan sebelas nama, ditambah dengan nama Encep Saepuloh yang merupakan mantan Sekda Kota Cimahi. Hal ini pun dikonfirmasi oleh Ahmad Gunawan, mantan Anggota DPRD Kota Cimahi bahwa terdapat sebelas pendaftar, baik itu dari kader PDIP maupun dari luar partai. Adapun rincian dari pendaftar tersebut terdiri dari tiga kader DPC, yaitu Ence Tarman Suwandi, Dadan Kurniansyah, dan Agung Yudaswara. Pernyataan tersebut menjadi tidak sesuai jika dibandingkan dengan data sepuluh orang hasil penjaringan, bahwa kader internal PDIP yang mencalonkan saat itu adalah Ence Tarman Suwandi dan Dadan Kurniansyah. Sedangkan Agung Yudaswara yang merupakan Anggota DPRD Cimahi Fraksi PDIP saat itu tidak tercantum dalam bakal calon yang dirilis pada media. Akan tetapi, nama tersebut masuk ke dalam tahapan penyaringan. Hal ini tentu menjadi rancu dan tidak jelas, sebab jika nama tersebut masuk ke dalam penjaringan, seharusnya menjadi dua belas orang bakal calon, dan tiga calon dari internal.

Komposisi hasil penjaringan yang berjumlah dua belas orang, sembilan orang dari unsur eksternal, serta tiga orang dari unsur internal partai mencerminkan adanya ketimpangan kesiapan kader partai dalam menghadapi kontestasi Pilkada. Selain itu, konteks lainnya adalah perspektif yang berpotensi muncul dari para bakal calon eksternal partai yang tidak mementingkan status keanggotaan partai dalam mencalonkan diri sebagai calon kepala daerah.

Permasalahan pertama adalah belum optimalnya kaderisasi partai dalam membentuk kader yang mampu berkontestasi, baik itu dari segi kepemimpinan, pengalaman, dan kesiapan finansial. Selain membutuhkan kajian yang lebih mendalam dalam menganalisis proses kaderisasi atau pembinaan anggota di internal PDI P, peneliti mencermati bahwa hal yang paling berat bagi kader adalah modal finansial dalam suksesi Pilkada, sehingga kecenderungan yang muncul adalah adanya relasi antara pemodal dan politisi yang berpotensi menimbulkan perburuan rente.

Permasalahan kedua adalah lumrahnya para kandidat yang muncul dari kalangan non partai, meskipun direkomendasikan partai namun tidak memiliki keanggotan partai politik, dan membangun komunikasi ke berbagai partai politik. Dengan demikian, baik itu permasalahan pertama maupun kedua, catatan penting bagi demokratisasi dan pembangunan politik di Indonesia adalah kaderisasi partai politik yang perlu dibenahi, sehingga masyarakat percaya bahwa partai politik mampu menghasilkan kader terbaik untuk memimpin bangsa dan negara. Peneliti mencermati bahwa tokoh-tokoh di luar partai tersebut milihat peluang besar pada masyarakat saat ini umumnya tidak mempercayai partai politik yang identik dengan perilaku koruptif, asalkan populer, karismatik, memiliki rekam jejak yang baik, serta memiliki akses terhadap modal finansial, modal sosial dan politik, maka kesempatan besar untuk berkontestasi tanpa status keanggotaan partai sangat dimungkinkan terjadi, seperti halnya ketokohan Anies Baswedan dan Ridwan Kamil yang keduanya menjabat sebagai Gubernur provinsi strategis.

Selanjutnya, kembali pada permasalahan rekrutmen dan seleksi kandidat pada Pilkada Cimahi tahun 2017 di internal PDI Perjuangan, muncul lagi nama lain dalam penjaringan kedua yang tidak dapat dikonfirmasi timeline penjadwalannya dan diumumkan pada tanggal 8 November 2016 dirilis resmi DPD PDIP Jawa Barat, karena dapat dikatakan dilakukan oleh tingkatan DPD atau DPP yang memunculkan nama Letkol Ngatiyana. Hal ini dinyatakan oleh Denta Irawan bahwa tingkatan DPD dan DPP berhak untuk menjaring bakal calon kandidat dalam Pilkada. Munculnya nama Letkol Ngatiyana menjadikan pernyataan Denta inkonsisten yang menyatakan bahwa semua nama diproses melalui DPC, nama tersebut muncul di tingkatan yang lebih atas dari DPC, meskipun secara prosedural tetap dilakukan di DPC, akan tetapi kans untuk direkomendasikannya lebih besar, karena muncul dari penjaringan yang lebih tinggi. Artinya, nama Letkol Ngatiyana direkomendasikan oleh pihak tertentu yang memiliki pengaruh besar, sehingga pihak DPD maupun DPP harus mengakomodir nama tersebut untuk kemudian ditindaklanjuti oleh pihak DPC.

Munculnya nama Ngatiyana merupakan proses dari rekrutmen tertutup yang dilakukan oleh tingkatan yang lebih tinggi dari DPC. Selain itu, tidak dapat dikonfirmasi bahwa nama tersebut muncul karena mendaftarkan diri secara pribadi atau melalui pihak lain. Namun peneliti mencermati bahwa, Ngatiyana dicalonkan atau didaftarkan oleh pihak lain, melalui jalur yang tidak dapat diakses sama sekali oleh para pengurus DPC. Hal ini dapat dilihat dari status Ngatiyana saat itu yang merupakan seorang TNI aktif. Regulasi mengatur bahwa TNI aktif tidak diperbolehkan untuk berpolitik, sehingga dapat dipastikan ada pihak lain yang mendorong Ngatiyana untuk maju sebagai calon walikota maupun wakil walikota pada Pilkada Cimahi tahun 2017. Secara sederhana, jika dilihat dari kerangka rekrutmen politik yang dijabarkan oleh Czudnowaki (dalam Matrler and Macinnis, 2002: 36), peluang keterpilihan Ngatiyana untuk direkomendasikan menjadi kecil apabila dilihat dari social background, apprenticheship atau political socialization, karena 
statusnya sebagai TNI dan jauh dari pemahaman politik di tingkat lokal, khususnya dalam mengelola dinamika politik pada pemerintahan daerah. Namun jika ditinjau dari konteks Initial Political Activity, Ngatiyana memiliki relasi dengan salah satu elit politik, yang beberapa kali menjadi pejabat tinggi negara, yaitu Luhut Binsar Panjaitan, karena dia pernah menjadi ajudannya.

Setelah nama-nama terkumpul, pihak DPC mulai melakukan uji komitmen sebagaimana syarat pencalonan partai, khususnya dalam membiayai pemenangan Pilkada. Sebagaimana pernyataan Ahmad Gunawan, mantan Anggota DPRD Kota Cimahi bahwa dari sebelas nama hasil penjaringan, hanya tersisa lima orang yang siap berkomitmen untuk biaya kampanye. Dengan demikian, bakal calon yang lain pun dinyatakan gugur dalam tahap penjaringan. Komitmen tersebut menjadi keniscayaan dalam perhelatan politik ini, sebab pemilihan langsung menjadikan biaya politik yang tinggi, sedangkan partai tidak memiliki sumber daya finansial yang cukup untuk membiayai pemenangan Pemilu.

Selanjutnya, para bakal calon tersebut mengikuti sosialisasi internal partai. Hal ini, bertujuan untuk mengenalkan para bakal calon kepada masyarakat Kota Cimahi. Selain itu, para bakal calon didorong untuk melakukan blusukan karena partai akan melakukan survei elektabilitas dan popularitas kandidat. Pada teknisnya, program pengenalan ini lebih terkonsentrasipadakaderinternal dankonstituen DPC PDIP Cimahi, sehingga kegiatan sosialisasi internal lebih banyak diselenggarakan di kantor DPC, kemudian mengundang masyarakat. Selain itu, giat sosialisasi calon dilakukan secara terbuka melalui alat peraga sosialisasi, seperti spanduk, brosur, dsb. Pada tahapan sosialisasi terbuka pun, para bakal calon dianjurkan untuk membuat sendiri alat sosialisasi mereka dan disebarkan di berbagai wilayah Kota Cimahi.

Setelah melakukan dokumentasi penjaringan, Tim Rekrutmen melaksanakan survei internal dan eksternal. Berdasarkan hasil survei tersebut, muncul tiga nama, yaitu Ikin Sodikin, M. Iskandar Subrata, dan Agung Yudaswara yang kemudian direkomendasikan kepada DPD untuk ditindaklanjuti ke DPP. Sebagaimana Indormasi dari Ikin Sodikin, mantan Ketua KPU Kota Cimahi dalam mengikuti setiap tahapan penjaringan, ia mengatakan bahwa hasil polling ada tiga besar yaitu saya, Pak Iskandar, dan Pak Agung. Pada tahapan ini tidak jelas namanama yang dikirimkan ke DPP, apakah sesuai dengan pernyataan Ahmad Gunawan dengan hasil penjaringanlimaorangatauinformasidariIkinSodikin (peserta penjaringan) dengan hasil penjaringan tiga orang. Namun pada konteks ini peneliti melihat bahwa lima orang tersebut adalah bakal calon yang siap berkomitmen, namun setelah dilakukan survei, akhirnya semakin mengerucut menjadi tiga orang. Meskipun DPC tidak memiliki kewenangan untuk menganulir, namun proses kegiatan penjaringan yang mengharuskan kandidat berpartisipasi secara finansial, serta kegiatan sosialisasi mereka di luar agenda partai menjadi ‘seleski alam', sehingga caloncalon pun mengundurkan diri.

Kemudian, dari wawancara dengan Ikin Sodikin, peserta penjaringan, menjelaskan bahwa ketiga nama tersebut, yaitu Ikin Sodikin, M. Iskandar Subrata, dan Agung Yudaswara telah lolos di tahapan penjaringan DPD PDIP Jawa Barat dan akan direkomendasikan untuk penyaringan kembali di DPP PDI Perjuangan (PDIP). Minimnya sumber pendanaan pada tubuh partai politik pada saat pemilihan umum menyebabkan partai-partai mencari sumber alternatif antara lain dengan cara memotong pendapatan anggotanya yang duduk di lembaga legislatif, membiarkan anggotanya mencari pendapatan dari proyek pemerintah, dan biaya kandidasi dari para calon legislatif dan kepala daerah (Mietzner, 2007).

Berdasarkan wawancara dengan Pengurus DPD PDI Perjuangan Provinsi Jawa Barat, Bedi Budiman, Peneliti mencermati bahwa penjaringan dalam DPC PDI P Cimahi tidak luput dari asistensi DPD Jawa Barat, sehingga pada prosesnya namanama tersebut masuk ke dalam bahasan penjaringan Pilkada di DPD PDIP Jawa Barat. Dengan demikian, setelah pendokumentasian hasil penjaringan di DPC, kemudian dilakukan uji komitmen dan survei, maka DPC PDIP Cimahi membawa tiga nama tersebut ke DPP untuk kemudian direkomendasikan ke DPP.

Pada proses penelitian beberapa dokumen di atas tidak dapat dikonfirmasi keberadaannya dan penyelenggaraan kegiatannya, seperti halnya tes psikologi dan tes tertulis. Sedangkan data dan informasi kelayakan dapat dianalisa dari formulir yang dikumpulkan, pemetaan politik dapat dilihat dari hasil survei, hasil wawancara dan komitmen politik lainnya dapat diverifikasi dengan dokumen tertulis dan kegiatan wawancara yang dilakukan DPC. Dengan demikian, pada tahapan ini berkasberkas yang diajukan sebagai bahan pertimbangan kepada DPP menjadi diragukan signifikansinya. Bahkan dapat dikatakan hasil tes tulis maupun tes psikologi dipandang tidak penting dibandingkan dengan data lainnya yang mesti disetorkan kepada DPP, seperti komitmen calon dalam pembiayan kampanye.

Kemudian, tahapan selanjutnya adalah penyaringan, Denta Irawan, mantan Ketua DPC PDI P Cimahi saat itu menjelaskan bahwa dalam kegiatan penyaringan itu isinya adalah bakal 
calon menyapaikan visi dan misi dan interview di DPP. Andi, mantan Sekretaris DPC PDIP Cimahi menambahkan bahwa setelah pemanggilan untuk interview, DPP mengadakan pembekalan dalam mengelola pemerintahan daerah, selain itu terdapat penilaian dalam pembekalan tersebut. Pada tahapan ini peneliti tidak dapat menjelaskan secara rinci prosedur penyaringan yang dilakukan oleh DPP dalam mengelola nama-nama yang dihasilkan dari penjaringan di tingkat lokal. Namun, hasil dari penyaringan justru merekomendasikan Letkol Ngatiyana. Ikin Sodikin, peserta penjaringan memberikan Informasi bahwa yang terpilih dalam proses penyaringan di DPP saat itu adalah orang baru yang tidak mengikuti proses penjaringan, bahkan jika dilihat statusnya tidak boleh mencalonkan sebagai walikota, karena menyalahi Undang-Undang, beliau merupakan seorang TNI aktif.

Keputusan DPP untuk mencalonkan Letkol Ngatiyana pada Pilkada Cimahi 2017 tentu menjadi mutlak harus diterima oleh DPC maupun DPD. Hal ini pun menuai berbagai respon dari peserta penjaringan bahkan dari publik pada umumnya. Hal yang menjadi polemik diantaranya adalah status Ngatiyana yang merupakan TNI aktif, akan tetapi bisa ditetapkan oleh PDIP sebagai calon yang akan berkontestasi pada Pilkada Cimahi 2017, padahal sudah jelas dikatakan dalam Undang-Undang bahwa TNI aktif tidak boleh berpolitik, baik itu dipilih maupun memilih. Fenomena ini menjadi pertanyaan besar bagi berbagai kalangan, namun Ikin Sodikin, peserta penjaringan, memberikan tanggapan bahwa tidak aneh sebetulnya keputusan yang diambil DPP tidak mengakomodir hasil penjaringan DPC, namun sangat disayangkan partai tidak memperhatikan usaha-usaha bakal calon yang telah melakukan sosialisasi dari jauh-jauh hari dan telah mengeluarkan banyak biaya untuk sosialisasi dan blusukan.

Peneliti mencermati bahwa dalam konteks pencalonan Letkol Nagatiyana ini menandakan adanya pengaruh elit yang lebih kuat, sehingga dapat mengalahkan tahapan prosedural yang menjadi acuan partai dalam melakukan proses rekrutmen. Jika ditelusuri, Letkol Ngatiyana merupakan seorang Gumil yang sempat dipercaya sebagai ajudan dari salah satu elit politik di Indonesia, yaitu Luhut Binsar Panjaitan (LBP), yang menduduki berbagai jabatan strategis pada masa pemerintahan Presiden Joko Widodo, seperti halnya Menko Polhukam, Menko Maritim, Menko Marves. Relasi kuat LBP terhadap PDI P mengindikasikan adanya proses 'titip menitip' untuk mensukseskan Letkol Ngatiyana sebagai pejabat politik di daerah.

Penetapan Ngatiyana sebagai kandidat yang direkomendasikan oleh PDI Perjuangan merupakan gambaran dari proses rekrutmen tertutup, meski sebelumnya partai mencitrakan rekrutmen terbuka. Dinamika yang terjadi, baik di pusat maupun daerah dalam proses rekrutmen tersebut, terhenti ketika elit politik telah mencapai kesepakatan. Peneliti mencermati bahwa Ngatiyana muncul sebagai kontestan berdasarkan rekomendasi elit.

\section{Perumusan Keputusan Calon PDIP Pada Pilkada Cimahi 2017}

Sebelum muncul kesepakatan dalam mencalonkan Ajay-Ngatiyana, sempat terjadi blunder di internal DPP, nama pasangan calon yang direkomendasikan adalah Ngatiyana-Denta. Hal ini dikonfirmasi oleh Denta Irawan bahwa sempat kejadian rekomendasi yang muncul adalah Ngatiyana-Denta, namun Denta memohon kepada DPP untuk meralat, selanjutnya Denta terus berkomunikasi dengan partai lain. Munculnya rekomendasi tersebut bagi peneliti bukan unsur ketidaksengajaan, melainkan hasil dari kajian Tim Seleksi di DPP. Dapat diartikan bahwa DPP percaya diri dengan mengusung pasangan dari internal partai, tidak memperhatikan koalisi partai di tingkat daerah. Pada proses ini Denta mengakui sempat ditegur oleh DPP karena tidak mau direkomendasikan oleh partai. Proses ralat keputusan tersebut dapat dikatakan bahwa DPP tetap memperhatikan kondisi politik lokal, meski pada dasarnya DPC tidak memiliki kewenangan, bahkan berkewajiban mematuhi keputusan partai.

Pasangan Ajay-Ngatiyana terbentuk karena Ajay telah memiliki dukungan dari tiga partai politik, yaitu PPP, PKB, dan PAN. Tim Ajay berupaya untuk membangun dukungan yang lebih kuat agar presentase kemenangan semakin besar. Ajay yang telah mendapatkan dukungan pun menjalin pertemuan dengan DPC PDIP. Perlu diketahui bahwa Ajay memiliki irisan dengan PDI P karena ia sempat mencalonkan diri sebagai Caleg DPR RI dari PDIP untuk wilayah Garut. Dengan demikian, pengurus DPC pun menganggap bahwa Ajay adalah kader partai, meskipun ia sempat menanggalkan PDIP dan menjadi kader PPP.

Setelah melakukan pertemuan dengan DPC PDIP, akhirnya mereka sepakat untuk koalisi. Kemudian tahapan selanjutnya adalah menentukan calon walikota dan calon wakil walikota. Ajay dan Ngatiyana pun bertemu dan membangun kesepakatan bahwa Ajay sebagai calon walikota, Ngatiyana sebagai calon wakil walikota. Tahapan lobi politik tersebut dapat dimenangkan Ajay berdasarkan 'isi tas' atau komitmen finansial Ajay terhadap partai koalisi dan pembiayaan pemenangan Pilkada. Sebagaimana pernyataan Denta Irawan, mantan Ketua DPC PDIP Kota Cimahi, bahwa saat itu Pa Ajay mencari wakilnya, karena telah didukung 
oleh tiga partai, kemudian disepakati adanya koalisi dengan PDIP, lalu diagendakan proses penentuan calon walikota dan wakil walikota, hasilnya Pa Ajay calon walikota karena lebih mampu berkontribusi dalam biaya pemenangan.

Setelah itu, seluruh partai pengusung berkoordinasi dengan DPP masing-masing untuk mengajukan keputusan rekomendasi yang akan didaftarkan ke KPU Kota Cimahi. Akan tetapi, DPC PDIP memiliki tugas tambahan untuk mengajukan pensiun dini Letkol Ngatiyana dari statusnya sebagai TNI aktif. Andi, Sekretaris DPC PDIP Kota Cimahi menjelaskan bahwa saat itu Andi yang mengurus pensiun Ngatiyana, sekaligus turut melengkapi berkasberkasnya juga. Setelah Surat Rekomendasi dari DPP masing-masing lengkap, serta Ngatiyana telah dinyatakan sebagai purnawirawan, maka tim koalisi PDIP, PPP, PKB, dan PAN yang mengatasnamakan Koalisi Cimahi Baru mendaftarkan Ajay-Ngatiyana ke KPU Kota Cimahi.

Setelah berkomunikasi dengan partai lain, Denta Irawan, mantan Ketua DPC PDIP Kota Cimahi menjelaskan bahwa ia mencoba untuk mengajukan pasangan Ajay-Ngatiyana dan menjelaskan dinamika politik yang ada. Selain komitmen finansial dari Ajay, Denta menambahkan bahwa ada pertimbangan peta politik dan segmentasi pemilih. Ajay dapat mewakili kalangan sipil, kemudian Ngatiyana dapat mewakili keluarga militer, seperempat wilayah Cimahi terdiri dari wilayah TNI baik itu kantor maupun asrama. Peneliti menilai bahwa kombinasi tersebut dapat diunggulkan dibandingkan dengan pasangan AsepIrma, dengan sosialisasi dan penempatan APK yang tepat, pasangan Ajay-Ngatiya dapat terus meningkatkan popularitas dan elektabilitasnya, terlebih situasi lainnya pun mendukung, yakni kondisi petahana yang terjerat kasus korupsi, sehingga berdampak pada elektabilitas dan citranya yang buruk di masyarakat.

Keluarnya keputusan DPP PDI Perjuangan dalam merekomendasikan pasangan Ajay-Ngatiyana pada Pilkada Cimahi tahun 2017 tidak terlepas dari dinamika desentralisasi, meski pada prosesnya tetap keputusan ada di DPP. Proses lobi-lobi politik di internal PDIP menggambarkan adanya pola desentralisasi dengan mendengarkan saran DPC dan memahami dinamika politik lokal. Meskipun desentralisasi tersebut dapat dikatakan masih 'setengah' karena terbatasnya kewenangan DPC secara tertulis. Akan tetapi, secara informal tergambarkan pola kerjasama atau kolaborasi antara DPC, DPD, dan DPP dalam merumuskan formulasi pasangan calon pada Pilkada Cimahi 2017.

Fenomena Ajay-Ngatiyana menggambarkan adanya pengaruh kekuatan oligarki dalam pencalonan di internal partai, yaitu ditetapkannya Ngatiyana sebagai calon dari PDI P tanpa harus mengikuti penjaringan dari awal, serta masih berstatus TNI aktif. Meski menggunakan kekuatan pengaruh oligarki, PDIP harus menyampingkan egonya untuk menjadi calon walikota, karena disebabkan kekuatan finansial yang dimiliki Ajay. Selain itu, Ajay pun memiliki dukungan tiga partai karena komitmen finansialnya juga, sehingga posisinya untuk menjadi calon walikota sangat kuat.

Dengan demikian, yang menjadi catatan baik itu pengaruh oligarki maupun pengaruh finansial perlu diimbangi dengan kredibilitas dan kapasitas calon itu sendiri, meski dalam proses penelitian banyak informan partai yang menyatakan bahwa tetap mengutamakan kapasitas dan kualitas calon, akan tetapi faktanya tidak dijadikan sebagai prioritas utama. Sebab jika ditelaah track record dari Ajay maupun Ngatiyana, keduanya tidak memiliki pengalaman signifikan dalam mengelola pemerintahan. Hal yang dihawatirkan adalah Ketika keduanya tidak memiliki pengalaman di pemerintahan ataupun di organisasi politik menyebabkan mereka tidak mampu untuk menjalankan tugas dan kewajiban mereka sebagai walikota dan wakil walikota, diantaranya mereka harus mampu menjalankan tugas untuk meningkatkan taraf hidup maupun kesejahteraan rakyat di daerahnya.

Ajay yang memiliki latarbelakang sebagai pengusaha, dihawatirkan beban biaya finansial yang dikeluarkan untuk pemenangan dipandang sebagai modal yang harus dikembalikan, bahkan harus kembali lebih besar. Faktanya setelah memenangkan Pilkada, Ajay terkena kasus korupsi, sehingga ia kehilangan jabatannya dan harus menjalani hukuman. Fakta ini menggambarkan minimnya kredibilitas kandidat yang dicalonkan. Kenyataan tersebut diperkuat oleh informasi dari Denta yang menjadi pendorong utama majunya Ajay menjadi calon Walikota, dan menyebutkan bahwa dia mendorong Ajay karena faktor modal ekonomi yang dimiliki Ajay sebagai seorang pengusaha. Sementara itu, Ngatiyana memiliki latar belakang militer dan juga tidak memiliki pengalaman di organisasi partai politik maupun pemerintahn.

Berdasarkan uraian terkait proses perumusan keputusan dalam penetapan kandidat walikota dan wakil walikota di internal PDI Perjuangan menunjukkan adanya kecenderungan kepemimpinan personal dan klientelistik, dalam hal tersebut di satu sisi akan menghambat proses demokratisasi dan kaderisasi di tubuh partai, di sisi lain akan menghambat transformasi dari budaya politik mobilisasi menjadi budaya politik otonom. Lebih jauh dari itu, akibat dari model kepemimpinan personal dan klientelistik ini, membuat partai menjadi kekuatan oligarkis (Haris, 2005). 
Dampaknya adalah pengambilan keputusan di internal partai menjadi tertutup dan hanya ditentukan segelintir elit. Hal ini menunjukkan adanya problematika dalam mekanisme internal partai dimana peran pengurus pusat masih sangat dominan dan seringkali bertentangan dengan aspirasi pengurus di daerah.

\section{SIMPULAN}

Berdasarkan hasil penelitian dan analisis terhadap data hasil penelitian, maka dapat disimpulkan bahwa rekrutmen dan seleksi kandidat walikota dan wakil walikota dalam tiga hal:

1. Berdasarkan pertanyaan riset dalam penelitian ini, maka dapat disimpulkan bahwa rekrutmen dan seleksi kandidat di internal PDIP pada Pilkada Cimahi 2017 diawali dengan kebijakan DPP PDIP dalam menetapkan aturan dan Tim Seleksi Bakal Calon. Namun, dalam prosesnya DPP memegang kewenangan dalam menetapkan rekomendasi calon, sehingga pola rekrutmen cenderung sentralistik.

2. Proses selektorat terjadi di DPC, DPD, hingga DPP, namun peran DPC dan DPD dalam hal ini lebih administratif karena lebih fokus terhadap dokumen kelengkapan bakal calon yang kemudian akan dikirmkan ke DPD dan DPP. Akan tetapi, secara politis tingkat DPC dapat memainkan peran untuk memastikan komitmen politik bakal calon dan pasangan calon yang tepat dalam kontestasi tersebut, sehingga terdapat relasi elit pusat dan daerah dalam menentukan formulasi kandidat.

3. Terpilihnya Ngatiyana dalam rekrutmen internal PDIPerjuanganmengisyaratkankuatnya pengaruh oligarki dalam menentukan rekrutmen dan seleksi di internal partai politik. Karena pencalonan ngatiyana yang muncul di akhir periode seleksi dan direkomendasikan oleh elit DPP PDI P menyebabkan DPC hanya bisa menerima keputusan yang tersebut. Sedangkah terpilihnya Ajay merupakan representasi pengaruh modal finansial atau model ekonomi, Ajay yang sempat tersingkir dalam seleksi awal pada akhirnya diperjuangkan DPC dan DPD PDIP Kota Cimahi dan Jabar untuk ditetapkan sebagai calon walikota berdasarkan pertimbangan kemampuan finansial yang dimilikinya untuk mengatasi problematika high cost dalam kampanye.

\section{DAFTAR PUSTAKA}

Amal, I. (1988). Teori-Teori Mutakhir Partai Politik. Yogyakarta: PT Tiara Wacana.

Ariwibowo, H., Setiyono, B., Martini, R. (2013). Pola Rekrutmen Pemilihan Calon Anggota
Legislatif Oleh Partai Demokrasi Indonesia Perjuangan (PDI P) Menjelang Pemilu 2014 Di Kota Semarang. Jurnal Ilmu Pemerintahan, 2(3), 1-13.

Axford, B., et.al. (1997). Politics an Introduction. London: Routledge.

Creswell, J. W. (2010). Research Design; Pendekatan Kuantitatif, Kualitatif dan Mixed. Yogyakarta: Pustaka Pelajar.

Czudnowski, M.M. (1975). 'Political Recruitment', in Fred I. Greenstein and Nelson W. Polsby (eds). Handbook of Political Science, v. 2, Micropolitical Theory, pp. 155-242. Reading, MA: Addison-Wesley.

Dalton, R J., et.al. (2011). Political Parties and Democratic Linkage. Oxford University Press.

Djuyandi, Y. (2018). Pengantar Ilmu Politik. Depok. Rajawali Press.

Febriani. (2016). PDI P Jaring 10 Tokoh Calon Walikota Cimahi. Diakses 28 Februari 2016, dari: https://www.pikiran-rakyat.com/ nasional/pr-01250510/pdip-jaring-10-tokohcalon-wali-kota-cimahi.

Fitriyah. (2020). Partai Politik, Rekrutmen Politik dan Pembukaan Dinasti Politik Pada Pemilihan Kepala Daerah (Pilkada). Politika, 11 (1), $1-17$.

Hanifah. (2016). PDI P Bakal Pecat Kader Minta Mahar untuk Calon Kepala Daerah. Diakses 30 September 2017, dari: https://www. merdeka.com/politik/pdip-bakal-pecat-kaderminta-mahar-politik-untuk-calon-kelapadaerah.html

Haris, S. (Ed.). (2019). Menimbang Demokrasi Dua Dekade Reformasi. Jakarta: Yayasan Pustaka Obor Indonesia.

Irawan, D. (2016). PDIP Buka Peluang Bagi Semua Bakal Calon di Pilkada Cimahi. DPD PDI Perjuangan Jawa Barat. https://pdiperjuanganjabar.com/kabar-cabang/pdip-buka-peluangbagi-semua-bakal-calon-di-pilkada-cimahi/.

Kartini, D S. (2015). Rekruitmen Calon Kepala Daerah Oleh Partai Gerindra. Cosmogov, 1(1), 105-123.

Katz, S.R., \& Crotty, W. (2014). Handbook Partai Politik. Bandung: Nusa Media.

Mietzner, M. (2007). Party Financing in PostSoeharto Indonesia: Between State Subsidies and Political Corruption. Contemporary Southeast Asia, 29(2), 238-63. 
Labolo, M. (2017). Partai Politik dan sistem Pemilihan Umum di Indonesia: Teori, Konsep dan Isu Strategis. Jakarta: Rajawali Press

Pamungkas, Sigit (2011). Partai Politik: Teori dan Praktik di Indonesia. Yogyakarta : Institute for Democracy and Welfarism.
Sianturi, K A. (2015). Memperkuat Fungsi Rekrutmen Partai Politik. Jurnal Legislasi Indonesia, 12(1), 1-22. 